\title{
ドライバ状態モニターの開発と運転支援システムの 警報提示方法の検討
}

$\begin{array}{lllll}\text { 正員 山㟝 } & \text { 初夫* } & \text { 非会員 小林 } & \text { 史和** } \\ \text { 非会員 山田 } & \text { 拓郎** } & \text { 非会員 } \text { 井東 } & \text { 道昌*** } \\ \text { 正員 中野 } & \text { 倫明** } & \text { 正 員 山本 } & \text { 新** }\end{array}$

\author{
Development of driver's Status Monitor and Warning Presentation Method of \\ Driver Support System
}

\begin{abstract}
Hatsuo Yamasaki*, Member, Fumikazu Kobayashi**, Non-member, Takuro Yamada**, Non-member, Michimasa Ito***, Non-member, Tomoaki Nakano**, Member, Shin Yamamoto**, Member
\end{abstract}

To develop a human-friendly driver support system, it is essential to detect the driver's status such as consciousness levels and looking aside. We have developed a driver monitoring system, which detect the driver's consciousness reduction and gaze direction change by image processing techniques. Furthermore, we have proposed a new warning method with this driver monitoring system. The effectiveness in this method has been verified using a driving simulator.

キーワード：ITS，ドライバ状態モニター，運転支援システム，警報提示，ドライビングシミュレータ

Keywords: ITS, driver's status monitor, driver support system, warning presentation, driving simulator

\section{1. まえがき}

この数年 , 車載システムや道路システムなど ITS (高度 道路交通システム) に関する各種のシステム開発と実用化 が急速に進められている。とくに車載の運転支援システム では, 画像とレーダーとの融合による走行状態検知システ ム, ACC (Adaptive Cruise Control) に代表される車間・車 速追従制御システム，ナイトビジョンによる歩行者検知シ ステムなど新技術による各種のシステムが市場に出始めて (る ${ }^{(1)(2)}$ これれらシステムは, 雨・霧・夜間など人間の 視覚を補う新しいセンシング技術の開発に負うところが非 常に大きい。一方でこれらのシステムがドライバに信頼さ れるシステムであるためには, 走行状態の検知だけではな く，運転中のドライバ状態を検知・監視することが重要で ある ${ }^{(3)(4)}$ 。走行状態の検知に加えて，このドライバ状態を検

\footnotetext{
名城大学情報センター

T 468-8502 名古屋市天白区塩金口 1-501

Center for Computers and Information Technology, Meijo University

1-501, Shiogamaguchi, Tempaku-ku, Nagoya 468-8502

** 名城大学大学院理工学研究科

T 468-8502 名古屋市天白区塩釜口 1-501

Graduate School of Science and Technology, Meijo University

1-501, Shiogamaguchi, Tempaku-ku, Nagoya 468-8502

*** (株) 東海理化

T 480-0195 愛知県丹羽郡大口町豊田 3-260

Tokai Rika Co., Ltd.

3-260, Toyota, Oguchi-cho, Niwa-gun, Aichi 480-0195
}

知することによって, 運転支援システムの警報提示方法を 変えることでドライバに信頼される警報提示が可能になる だけでなく, 意識低下などの検知によって安全性の向上に も大きく貢献できると考えられる。

ドライバの状態検知の対象には, 意識低下, 脇見, 携帯 通話に伴う過度の意識集中, 疲労などが挙げられる ${ }^{(3)}$ 。意 識低下や脇見のドライバ状態を検知するには, 車載カメラ で撮像した画面から顔領域を検知し，光の顔領域からまば たきや視線を検出することが必要となる。さらに, 意識低 下の検知には, まばたきの閉眼時間の変化から光の人の意 識状態を推定することが必要となり，視線検知では顔方向 と眼球方向の検出が重要となる。ドライバ状態検知のため には , これらの技術を 1 つのシステムとして実現しなけれ ばならない。

従来研究については, ドライバ状態の 1 つである意識低 下検知に関しては, 筆者らの研究を含めた研究例が報告さ れている ${ }^{(5)(6)}$ 。脇見については, 視線方向の検出 ${ }^{(7)(8)}$ や脇見 の行動解析を行っている報告はあるが, システムとして実 現しようとしたものは多くはない( ${ }^{(1)}$ 。またた, 運転時の注 意力をモニターする報告 ${ }^{(11)}$ や携帯通話に伴う過度の意識 集中を視線の動きから解析しようとする試みも行われてい る ${ }^{(12)}$ 。しかし，どの報告もドライバのひとつの挙動につい てのもので, ドライバの状態の検知・監視全体についての 研究報告は少ない(13)(14)。

また，警報の提示についても，警報音の感覚評価からメ 
ンタルモデルの視点での研究, さらには警報音の設計指針 のための緊急度マップの作成などの研究報告 ${ }^{(15) \sim(19)}$ はある が，ドライバ状態との関連での報告例は見当たらない。

筆者らは意識低下と視線検知機能を持つドライバ状態モ ニターを開発し，これを用いた運転支援システムの警報情 報提示方法を提案して，検証実験によって产の有効性を検 証したのて報告する。

\section{2. ドライバ状態モニターの役割り}

ドライバ状態モニターとは運転中のドライバの状態を検 知・監視するシステムで, 兴の検知対象には安全な運転に 支障をきたす意識低下，脇見，携帯通話による過度の意識 集中，疲労などがある。

图 1 はドライバ状態モニターの役割りを示したものであ る。これまでの運転支援システムでは, 弚の車の走行状態 (先行車両との車間距離, 自車や先行車両の速度・加速度な ど）だけで警報提示されることが多かったが，ドライバに 信頼されるシステムとするには運転中のドライバの状態も 検知することが必要である。

ドライバ状態の検知によって運転支援システムの安全性 やドライバの信頼性は向上するが, 弚の実現は容易なこと ではない。運転支援システムの機能向上やシステムとして の費用効果さらに技術的な実現の可能性から，ドライバ状 態モニターには先ず意識低下と脇見の検知が必要と考えら れる。特に，意識低下の検知が最重要と考えられる ${ }^{(3)(5)(6) 。 ~}$

乥のためには, 1) 車載システムとして必要な照度変化に 強い撮像システム，2) 撮像した画像から顔領域や目領域の 検出，3) 検出された画像からまばたきや視線方向の検知， 4）まばたきから意識低下レベルの推定，5) 視線方向から脇 見の検知などの技術開発が必要となる。

本論文では, 上記の技術課題に対する解決方法と運転支 援システムに走行状態だけでなくドライバ状態で不可欠な 意識低下を検知することの有効性について述べる。

3. ドライバ状態モニターの機能と方法

〈3.1〉全体システム図 2 は開発したドライバ状態 モニターの全体の処理の流れを示したものである。このモ ニターシステムでは, 車載用に開発した撮像システムで顔

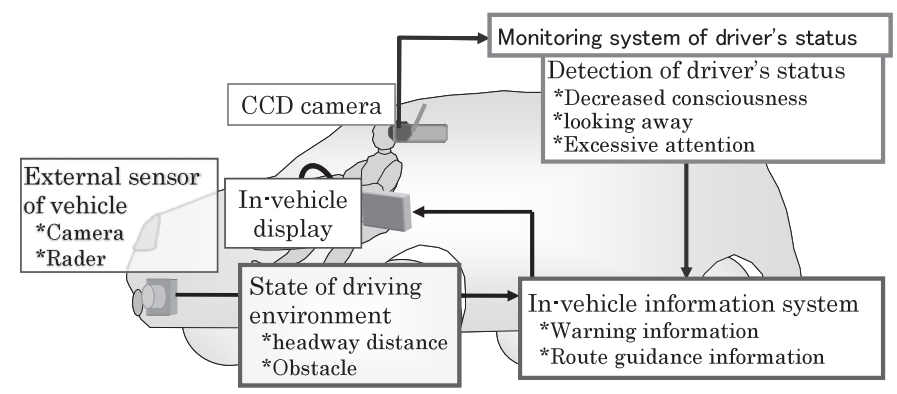

図 1 ドライバ状態モニターの役割り

Fig. 1. Role of driver's status monitor for driver support system.
画像を撮像し，顔領域・目領域を検出して，弚れからまば たきと視線の方向を計測する。光して，まばたきの閉眼時 間の変化から意識低下レベルを, 顔の向きや眼球の方向か ら視線方向を検知する。

図 3 はインナミラー位置に搭載するために開発した撮像 システムである。この撮像システムは夜間の低照度時から 昼間の高照度時まで安定に顔画像を撮像できるように，近 赤外パルス光投射方式を採用している ${ }^{(20)}$ 。撮像システムで は波長 $850 \mathrm{~nm}$ のLED を多数配列し, 対象物にパルス光を 投射して产の間だけシャッタを開いて CCD カメラで受光 する。図 3(a) に撮像システムの構成を, 図 3(b) にインナ ミラー搭載用に試作した撮像システムの外観を示す。

撮像した画像から眼領域の検出には, 3 層構造のニュー ラルネットワークによる方法を用いている(21)。先ず候補領 域を切り出し, 低解像化処理後に 4 方向エッジ特徵抽出処 理を行ってニューラルネットへ入力する。

ニューラルネットの学習に使用する学習パターン画像は 両眼と上唇を $80 \%$ 以上含むものとし, 兴の中心を教師信号 として学習させる。学習パターン画像として 80 種, 学習 抑制パターンとして 30 種用い, 学習回数として 60,000 回

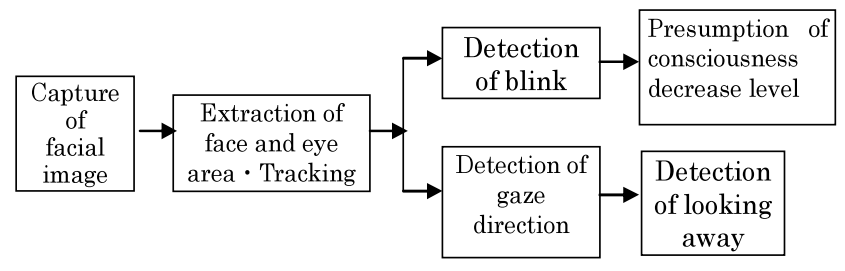

図 2 ドライバ状態モニターの処理の流れ

Fig. 2. Flow chart of driver's status monitor.

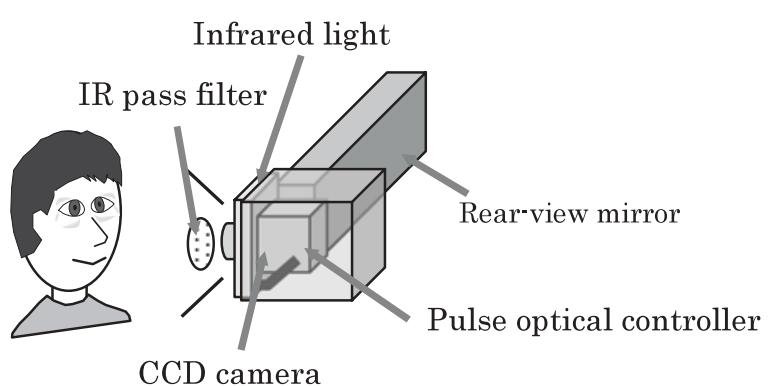

(a) Composition of image capturing system

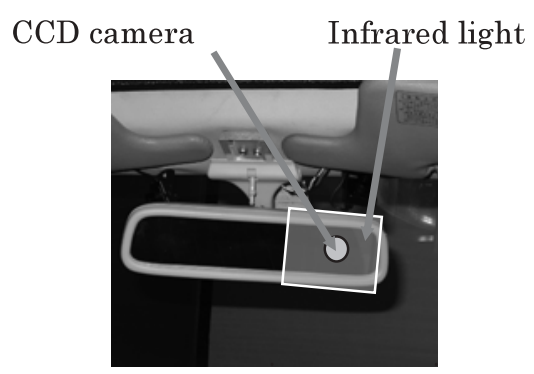

(b) Image capturing system in use

図 3 インナミラー搭載用に開発した撮像システム Fig. 3. Developed image capture system at the rearview mirror position. 

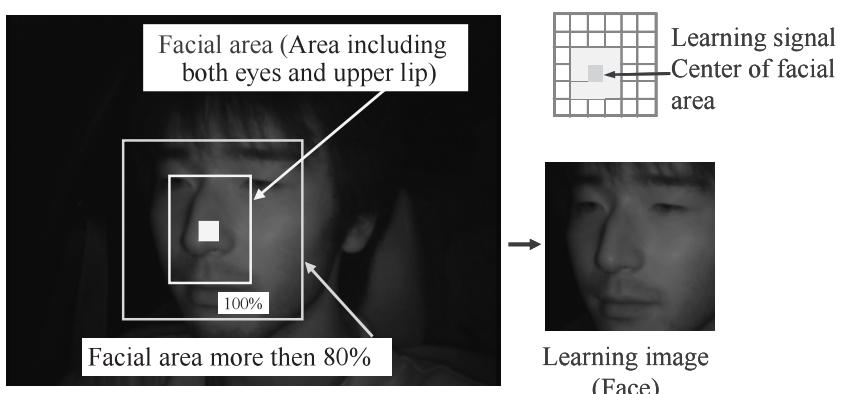

(Face)

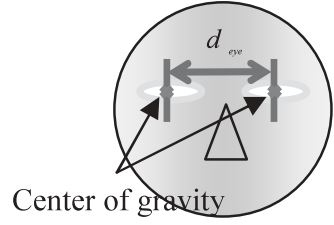

(a) For the front

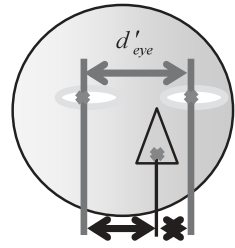

(b) For the facial

图 6 顔方向の検出原理

Fig. 6. Facial direction's detection principle.

图 4 学習パターンの定義

Fig. 4. Definition of learning pattern.

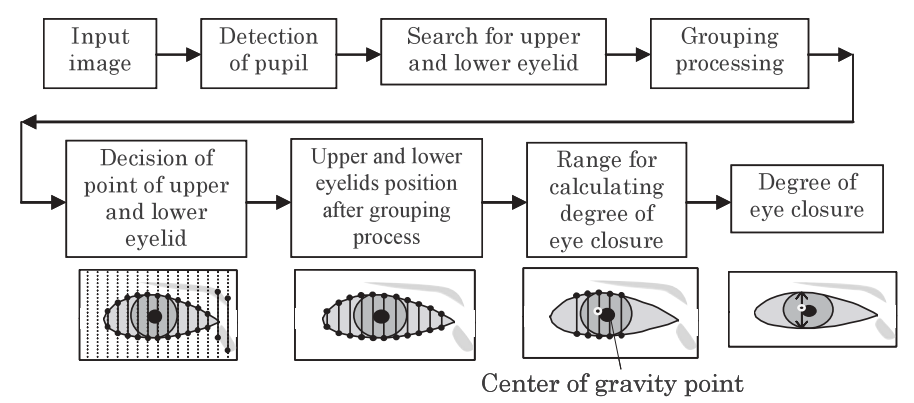

図 5 まばたき検出方法

Fig. 5. Detection method of a blink.

行った。この樣子を図 4 に示した。同樣な手法により，眼 領域の検出を検出された顔領域内にて行った。眼領域の検 出速度を上げるために, 眼領域の半分より上部をスキャン している。

\section{〈3.2〉まばたき検出による意識低下の検知}

〈3.2-1〉 まばたきの検出まばたきは上下まぶたたの 開閉によって検出する。图 5 はまばたきの検出方法を示し たものである。人の顔には個人差があり，とくに眼周辺は 個人に依存する特有のしわや膨らみがある。これらに影響 され難くするために，得られた眼領域に対して垂直方向の 切断面に沿って微分して黑目を中心にして上下まぶたたを検 出する。安定に上下まぶ氵たを検出するために，5 本の切断 線を用い, 光の上部および下部 5 点の濃度変化の平均值を

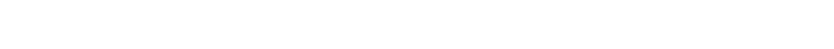
の動きに対応する。撮像画像の大きさは，640 画素 $\times 480$ 画素, 眼領域のサイズは約 80 画素 $\times 40$ 画素, 上下まぶた の間隔は約 15〜18 画素である。

〈3.2. 2〉 意識低下の検知意識低下が起きるとまばた きの閉眼時間が長くなる。さらに，この長い閉眼時間の割 り合い (長い閉眼時間率と呼ばれる) は, 意識低下の状態 とよい対応をしていることが報告されている ${ }^{(8)}$ 。この研究 では, 前述で得たまばたきの長い閉眼時間率の割合で, 光 の被験者の意識低下の状態を推定する。

〈3.3〉 視線方向の検知

〈3 3 1 1 顔方向と眼球方向の検出 運転中のドライ バの視線を正しく検出するためには, 顔方向と眼球方向を 分離して検出することが必要である。

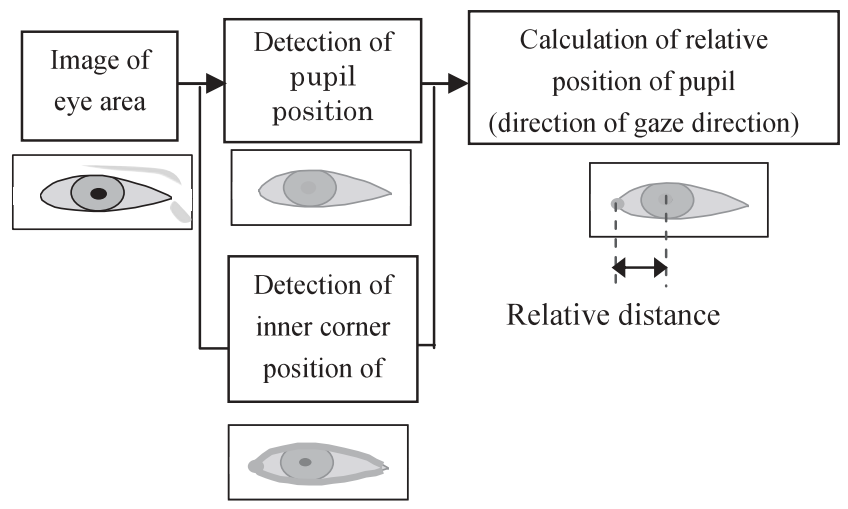

図 7 眼球方向の検出と方法

Fig. 7. Detection and method of eyeball direction.

図 6 は, 顔方向検出の原理を示したものである。顔方向 と光の角度は顔の特徵点である鼻の重心点と両眼の重心点 間の距離により算出する。先ず正面顔において両眼の重心 点距離 $\mathrm{d}_{\mathrm{eye}}$ を算出し, 次に任意の顔の角度 $\theta$ のときの両眼 の重心点間距離を求める。光の距離を $\mathrm{d}_{\mathrm{eye}}^{\prime}$ とすると, この ときの顔の角度 $\theta$ は

$$
\theta=\cos ^{-1}\left(\mathrm{~d}_{\text {eye }}^{\prime} / \mathrm{d}_{\text {eye }}\right)
$$

より求められる。

また, 顔の方向は両眼重心点と鼻の中点の距離 $\mathrm{D}_{\text {right }}$ お よび $\mathrm{D}_{\text {left }}$ より検出する。例えば， $\mathrm{D}_{\text {right }}>\mathrm{D}_{\text {left }}$ なら左方向， $\mathrm{D}_{\text {right }}<\mathrm{D}_{\text {left }}$ なら右方向となる。

眼球方向は眼領域画像から得られる目頭と瞳孔の重心点 の相対的距離から算出する。

図 7 は眼球方向の検出方法を示したものである。視線の 方向はこのようにして算出した顔方向と眼球方向を加味し て検出される。

\section{4. ドライバ状態モニターの性能}

〈4 1〉 意識低下の検知性能の評価は検証実験によっ て行った。被験者 (11 名) には前景画面を見てもらってド ライビングシミュレータに約 1 時間座ってもらった。この 時の顔画像を撮像システムで撮像し，谷のときの意識状態 を自己申告してもらった。自己申告は，“正常”，“眠い”， “かなり眠い”の3 段階とした。実験結果はドライバ状態モ ニター (長い閉眼時間率を計測) と自己申告との関係でま とめた。意識状態の信頼性を上げるために, 自己申告時に 
別のカメラによるビデオ画像による視察判定も加味した。 表 1 は关の視察判定の基準を示したものである。

図 8 は被験者ごとの意識状態と長い閉眼時間率の関係を 示したものである。各被験者について产れ呑れ良い対応を 示していて，この結果からまばたきの長い閉眼時間率から その人の意識低下状態が推定できることがわかる。

〈4 2〉視線方向の検出被験者にドライビングシュミ レータのドライバ席に座ってもらい, 既開発の実験システ

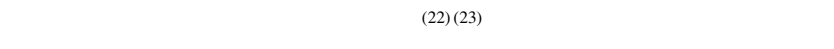
視力 1.0 以上の 20 才代学生 5 人で, 顔方向を右 40 度から 左 60 度まで変化させて測定した。

表 2 は炎の測定結果を示したものである。この表で, 顔 方向の 40 度はドライバが右サイドミラーに顔を向けた場 合 , 0 度は正面に顔を向けた場合 , -60 度は左サイドミラー

\section{表 1 意識レベルの視察判定基準}

Table 1. Reference on conscious levels by watching.

\begin{tabular}{|c|l|l|}
\hline & \multicolumn{1}{|c|}{ Facial features } & \multicolumn{1}{c|}{ The others } \\
\hline Normal & $\begin{array}{l}\text { Fast and periodic blinks } \\
\text { Quick eye movement }\end{array}$ & Straight posture \\
\hline Drowsy & $\begin{array}{l}\text { Slow rate of blinks and eye } \\
\text { movement }\end{array}$ & $\begin{array}{l}\text { Yawn, mumble and } \\
\text { reseat }\end{array}$ \\
\hline Heavily drowsy & $\begin{array}{l}\text { Appearance of blinks of 0.5 s } \\
\text { closing time }\end{array}$ & $\begin{array}{l}\text { Rolling and bowing } \\
\text { of the head }\end{array}$ \\
\hline
\end{tabular}

$\square$ Normal $\square$ Drowsy $\square$ Heavily drowsy

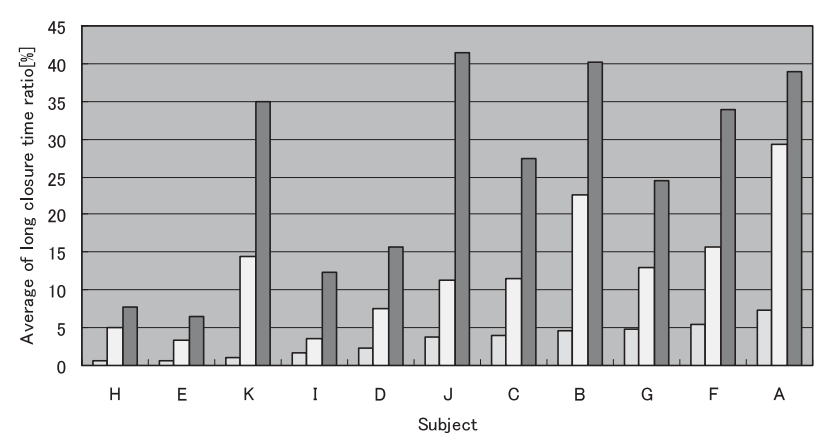

図 8 意識低下レベル推定の結果

Fig. 8. Presumption on drowsy level by the average of long closure time ratio for each subject.

\section{表 2 視線方向検出の精度}

Table 2. Measuring accuracy for gaze direction.

\begin{tabular}{|c|c|c|c|c|c|}
\hline \multirow{2}{*}{\begin{tabular}{|c} 
Facial angle \\
[deg]
\end{tabular}} & \multicolumn{5}{|c|}{ Accuracy [deg] } \\
\hline & Subject A & bject B & Subject C & Subject D & Subject $\mathrm{E}$ \\
\hline 40 & 8.9 & 10.2 & 7.8 & 8.2 & 9.1 \\
\hline 30 & 3.2 & 11.3 & 6.6 & 5.9 & 6.9 \\
\hline 20 & 2.4 & 4.0 & 5.1 & 5.4 & 5.5 \\
\hline 10 & 4.6 & 5.1 & 5.6 & 4.1 & 4.9 \\
\hline 0 & 4.5 & 5.8 & 4.8 & 4.6 & 4.1 \\
\hline-10 & 2.5 & 4.9 & 4.0 & 3.5 & 5.0 \\
\hline-20 & 3.1 & 5.2 & 5.3 & 4.0 & 4.7 \\
\hline-30 & 6.1 & 6.9 & 5.9 & 5.9 & 6.6 \\
\hline-40 & 5.2 & 4.0 & 4.9 & 3.8 & 5.1 \\
\hline-50 & 4.3 & 5.6 & 4.2 & 4.6 & 5.6 \\
\hline-60 & 6.0 & 5.2 & 4.9 & 5.1 & 6.1 \\
\hline
\end{tabular}

に顔を向けた場合の視線角度である。この結果から，視線 方向の検出精度は両サイドミラー角度間で \pm 5.4 度である。

\section{5. ドライビングシミュレータへの適用}

車載装置としてドライバ状態モニターを装備することの 有効性を評価できるようにするため, 既開発のドライビン グシミュレータに同モニターを装備した。

これによって，このシミュレータでは(1前方車両や割り 込み車両との車間距離, 障害物有無など実走行状態の模擬 に加えて , (2)ドライバの運転状態に応じた運転支援の警報 の提示方法を検討することができる。

〈5 1〉 ドライビングシミュレータの構成 このドライ ビングシミュレータはドライバの運転状態を検知するため のドライバ状態モニターシステム, 運転支援情報提示シス テムおよび画像生成システムで構成されている。

図 9 はこのドライビングシミュレータの外観写真で , ド ライバ状態モニターシステムと運転支援情報提示システム は車のカットボディー内に装備されている。

図 10 は画像生成システムの構成である。自車位置や摸 擬視界を生成するコンピュータからのシミュレーション映 像との同期をシミュレータ本体にて行い, プロジェクター からシミュレーション映像がスクリーンに投影される。ま た, シミュレータ制御部を経由してドライバ状態モニター システムから情報提示に関するデータが情報提示システム

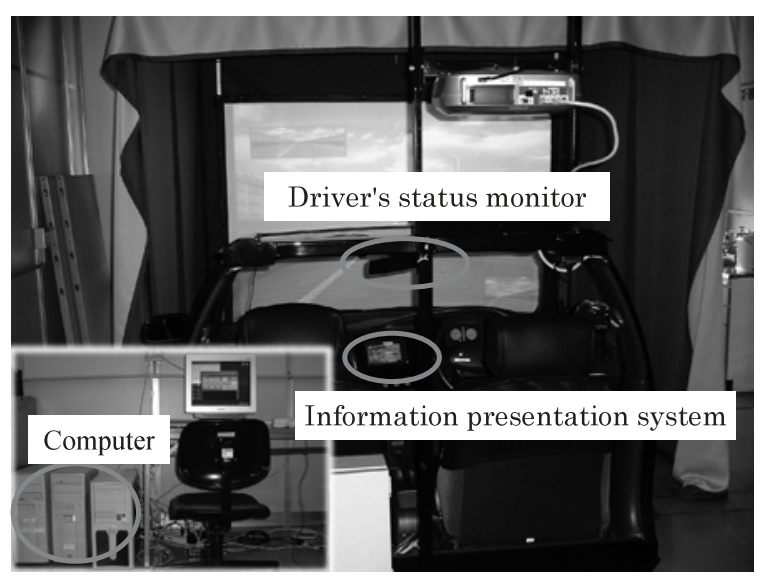

図 9 ドライビングシミュレータの外観写真

Fig. 9. Outlook of developed driving simulator.

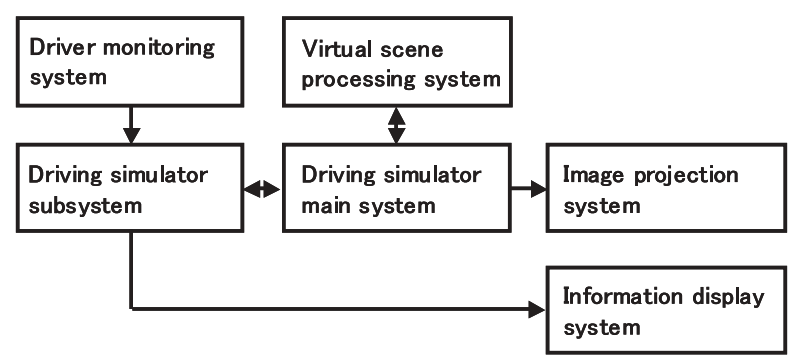

図 10 画像生成システムの構成

Fig. 10. Block diagram of image generation system. 
に送られ，各種警報提示データか情報提示システムに出力 される。

運転支援の情報提示システムは, 通常はナビゲーション システムとして動作するが，警報提示のときにはナビ画面 にスーパーインポーズして警報情報が提示される。このシ ステムでは画像表示と一緒に音や音声でも警報提示させる ことができる。

〈5. 2〉運転支援情報提示システム 運転支援情報提示 システムは, ドライバの運転中の意識状態とドライバの年 代 (高齢者と非高齢者) に応じて提示方法が検討できるシ ステムである。ここでは，この論文の主旨から警報の提示 方法について述べる。

このシミュレータでは, 運転中のドライバの意識状態を 検知し，㚇の情報に基づいてドライバにわかりやすい警報 を提示する方法が検討できる。

図 11 は走行状態とドライバの意識状態を考慮した警報 提示の基本的な考え方を示したものである。横軸はドライ バの意識状態で，右側ほど意識状態が低いこと（意識低下 や居眠りに相当）を表わしている。縦軸は走行状態（たと えば, 前方車両との車間距離) で, 上側ほど車間距離が短く 危険が大きいことを表わしている。車間距離が長く, 意識 状態が高い場合 (正常な運転状態) では “助言”程度の情報 でよいが，車間距離が短い場合あるいは意識状態が低い場 合には“注意を促す”情報が必要であり，車間距離が短く， かつ意識状態が低い場合には“警告”といった強い警報が必 要である。

本警報提示方法では，“助言”,“注意”,“警告”の各状況に 応じて，ドライバへ危険や緊急を伝える度合い(以下，緊急 度とよぶ）を変えた警報を提示する。緊急度が低い場合は， ドライバの注意を引く程度の警報音や表示を用い，煩わし さを最小限に抑えた警報とする。緊急度が高い場合は，危 険を短時間に知らせる耳障りな警報音を用いる。本警報提 示方法は，緊急度の大小に対応した複数の警報を備え，ド ライバ状態モニターによる意識状態とレーダーなど車載セ

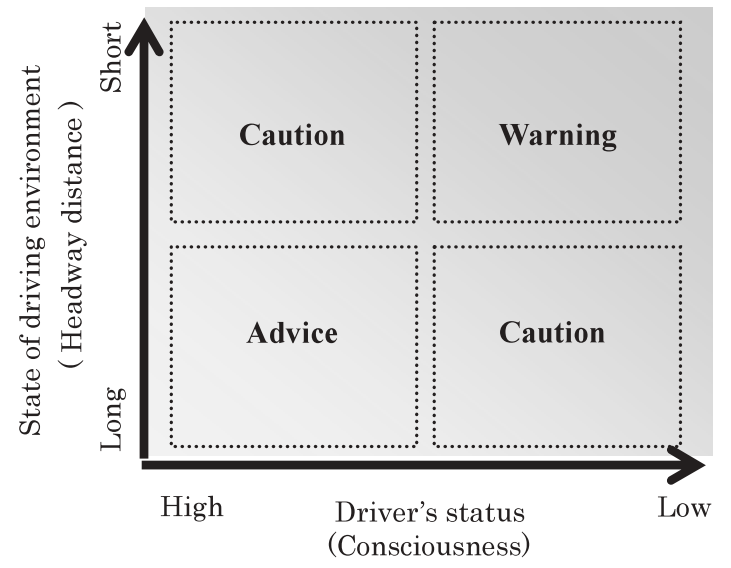

図 11 警報提示のコンセプト

Fig. 11. Warning concept based on driver's status and state of driving environment.
ンサによる車間距離の情報から緊急度を判断し，適切な警 報を切り替えて提示する方法である。

運転支援情報提示システムでは, 緊急度の大小の判定方 法 , 緊急度の違いに応じた警報提示の手段やタイミングな どを検討することや，種々の警報提示方法の有効性を再現 性よく比較・検証することが容易にできる。

\section{6. 意識状態検知による警報提示の検証実験}

ドライビングシミュレータを用い,ドライバ状態モニター 機能を用いた警報が従来の警報に比べて有効か否かを検証 する実験を行った。この実験では, ドライバ状態モニター の一機能である意識状態検知により警報提示を行い, ドラ イバ状態モニター機能が基本的に警報提示に効果があるか 否かを検証することを主目的とした。

〈6. 1〉 実験方法 警報は, 音の高さ, 断続周期, 音圧 を変化させることで危険度を変化させ, 訴える危険の違い がわかりやすい警報とする。図 12 に従来の警報と本警報 のスペクトルグラムを示す。(a)の従来の警報は, 現在の車 間・車速追従制御システムなどの代表的な警報音を参考とし て作成し，本警報の意識正常用警報としても使用する。(b) の本警報は従来の警報と比べて高周波成分を多く使用した 意識低下用警報として作成した。従来の警報では， $800 \mathrm{~Hz}$ から $1000 \mathrm{~Hz}$ の周波数成分を多くした複合音とし，音圧を $55 \sim 58 \mathrm{~dB}$ (0.6 秒提示) として意識状態に依らず常に同じ 警報音を提示するものとする。一方，本警報では，意識状 態が高い正常時は従来と同じ警報音とし, 意識状態が低い 場合には音圧レベルを $60 \sim 64 \mathrm{~dB}$ 程度 (2.7 秒提示) とし た高周波成分を多く含んだ複合音を用い，これらを意識低 下の高低により切り替えて提示する警報とした。

実験場面は，ドライバの“意識状態が高い場合”ならびに “意識状態が低い場合”の2 場面とした。ドライバの意識状 態が低下したか否かの判定は, シミュレータの運転が走行 車線から 1 車線分外れた場合とした。事前の実験により， このような場合には意識状態は相当低下し，居眠り運転の 直前であることを確認した。意識状態が低い場合は，従来

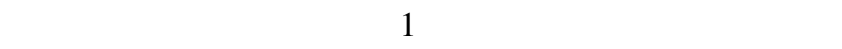
した。意識状態が高い場合には，警報への慣れによる反応 時間への影響をできる限り排除するため警報提示の間隔も

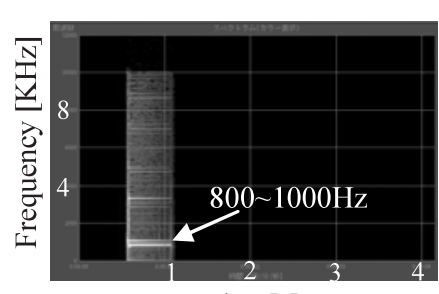

Time[s]

(a) Conventional warning

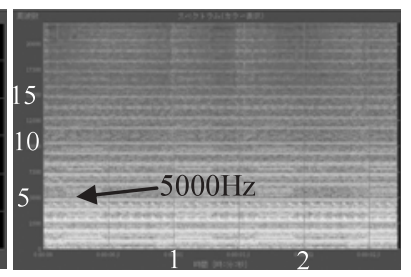

Time [s]
図 12 従来の警報と本警報のスペクトルグラム Fig. 12. Conventional and proposed warning sound spectrum. 
4 回ずつランダムとした。

評価方法は, 反応時間による客観評価と被験者が緊急と 感ずる度合いを答える主観評価の両方とした。反応時間は， 警報提示に気がついたとき運転支援情報提示システムに装 備されたボタンを押してもらうことにより計測した。主観 評価では, 上記意識状態が低い場面について，被験者に対 して実験後に従来の警報に対する本警報の緊急と感ずる度 合いを 5 段階の尺度で答えてもらった。このとき，従来の 警報は 5 段階の中間の 3 とし，緊急性を感ずる場合は 4 , 非 常に感ずる場合は 5 , 同程度の場合は 3 , 緊急性を感じな

\section{表 3 実験条件}

Table 3. Experimental conditions.

\begin{tabular}{|c|c|}
\hline Item & Contents of experiment \\
\hline Subject & Young (21 24years old) \\
\hline $\begin{array}{c}\text { Subject's } \\
\text { state of } \\
\text { consciousness }\end{array}$ & $\begin{array}{c}\text { Normal:5people } \\
\text { Decrease (self-return+Inspection judgment) :10people }\end{array}$ \\
\hline $\begin{array}{c}\text { Warning } \\
\text { presentation }\end{array}$ & $\begin{array}{c}\text { - Normal consciousness (Conventional warning) } \\
\text { - Decreased consciousness (Proposed warning) }\end{array}$ \\
\hline Test time & About 30 60minutes \\
\hline $\begin{array}{c}\text { Distance to } \\
\text { display }\end{array}$ & $75 \mathrm{~cm}$ \\
\hline
\end{tabular}

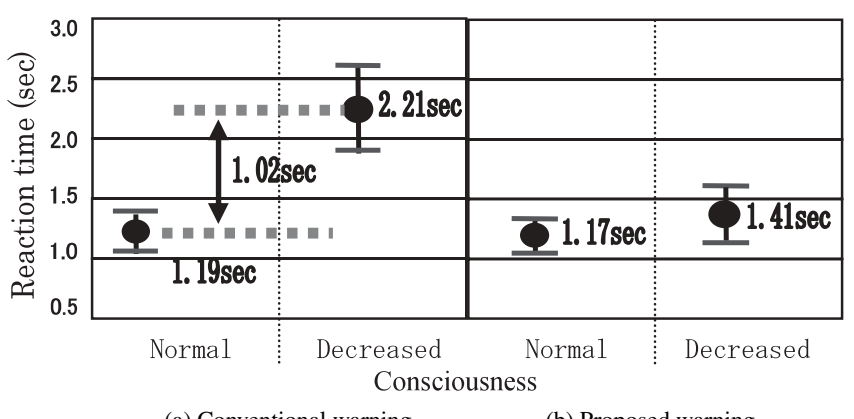

(a) Conventional warning

(b) Proposed warning

図 13 従来の警報と本警報の客観評価 (反応時間) 実験結果

Fig. 13. Objective evaluation (reaction time) experimental results of conventional warning and proposed warning.

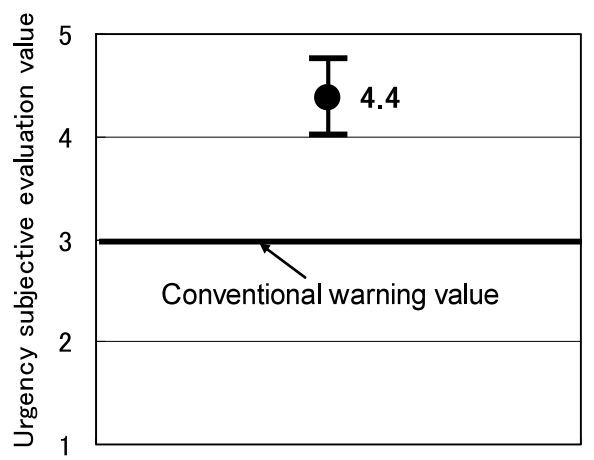

図 14 従来の警報と本警報の主観評価 (緊急性) 実験結果

Fig. 14. Subjective evaluation (emergency) experimental results of conventional warning and proposed warning.
い場合は 2 , ほとんど感じない場合は 1 と答えてもらった。 表 3 に実験条件を示す。

〈6. 2〉 実験結果図 13 は客観評価 (反応時間計測) の結果を示したものである。従来の警報と本警報を比較す ると, 両者とも意識状態が高い場合 (正常な運転状態) は 短時間で反応していることがわかる。意識状態が低い場合 には，本警報は意識状態が高い場合と同程度の時間で反応 できているが, 従来の警報では, 反応時間は約 1.02 秒程度 遅れることがわかる。この時間遅れは, 実際の運転場面に 換算すると，時速 $60 \mathrm{~km}$ で走行しているとき $17 \mathrm{~m}$ の距離 に相当し，従来の警報では意識低下した運転では警報に気 づくのが遅れ, 前方車両との接触の危険が大きくなること を示唆している。図 14 に主観評価の結果を示す。従来の 警報と本警報 (意識低下用警報) を比較すると, 緊急性が 高くなっており，本警報の有効性が確認できる。以上のよ うに,ドライビングシミュレータを用いた実験で客観評価 と主観評価を行った結果, 従来の警報に比べ意識状態を検 知する本警報は, ドライバ状態の高低に依らず安全性に有 効であることが検証された。

\section{7. むすび}

ドライバに信頼される運転支援システムの実現には，ド ライバの意識低下や脇見などドライバの運転状態の検知や 監視が欠かせない。動画像処理によって撮像システムで撮 像したが画像からドライバの意識の低下と視線の動きを検 知するドライバ状態モニターシステムを開発した。さらに， このモニターシステムを用いた警報提示システムを提案し， この方法の有効性をドライビングシミュレータによる検証 実験で確認した。

今後は , ドライバ状態モニターシステムについては , 眼 鏡やサングラスをかけたドライバへの適用，警報提示方法 については, 多くの被験者による定量的実験や高齡者に対 する効果の検証を行う予定である。

謝 辞

本研究の一部は科研費助成 (課題番号 15300066)，およ びNEDO の地域新生コンソーシアムプロジェクト“ヒュー マンセンタードITS ビューエイドシステム”の支援を受け て行われた。また, 実験においてはアイシン・エイ・ダブ リュ (株) のITS 企画部の協力を得た。記して感謝の意を 表します。

(平成 16 年 10 月 28 日受付, 平成 17 年 3 月 3 日再受付)

$$
\text { 文献 }
$$

( 1 ) H. Tanaka: "Safety Improvement Technology by utilizing Intelligent Driver Assistance System for Safe Driving", Vol.58, No.5, pp.88-94 (2004) (in Japanese)

例えば，田中宏明：「知的運転支援システムによる安全性向上技術」, 自動車技術, Vol.58, No.5, pp.88-94 (2004)

(2) 例えば, 以下の HP(URL) TOYOTA: http://www.toyota.co.jp/jp/ NISSAN: http://www.nissan-global.com/JP/ HONDA: http://www.honda.co.jp/tech/ 
（3）中野倫明·山本 新:「自動車におけるヒューマンインタフェースの研 究開発動向」, 信学報・システムソサイエティ大会, DT-2-1,pp.357-358 (2000)

(4) K. Hiramatsu: "Human Interface. Human-Machine-Interface in an Intelligent Vehicle”, Vol.56, No.3, pp.4-7 (2002) (in Japanese)

平松金雄 : 「自動車運転とヒューマンインタフェース」, 自動車技術, Vol.56, No.3, pp.4-7 (2002)

( 5 ) : "Adaptability of Drowsiness Level Detection that Measures Blinks Utilizing Image Processing to Changes in the Ambient Light", Journal of Society of Automotive Engineers of Japan, No.976, pp.231-234 (1997) (in Japanese)

金田雅之・小厚 豪・上野裕史 : 「光環境の変化に適応する顔画像処 理による居眠り運転検知」, 自動車技術解学術講演会前刷集, No.976, pp.231-234 (1997)

(6) K. Adachi, N. Hamada, T. Nakano, and S. Yamamoto: "Blink Measurement to Detect a Driver's Drowsy State by Moving Image Processing", Trans. IEEE Japan, Vol.124, No.3, pp.776-783 (2004-3) (in Japanese)

例えば，足立和正・濱田尊裕・中野倫明・山本＼cjkstart新：「ドライバの意 識低下検知のための動画像処理によるまばたき計測」, 電学論 C, 124 3, pp.776-783 (2004-3)

( 7 ) K. Abe, M. Ohuchi, S. Ohi, and M. Ohyama: "Eye-gaze Input System Based on the Limbus Tracking Method Using Image Analysis", The Journal of the Institute of Image Information and Television Engineers, Vol.57, No.10, pp.1354-1360 (2003-10) (in Japanese)

阿部清彦・大内幹夫 ·大井尚一・大山 実 : 「画像解析による強膜 反射法を用いた視線入カシステム」, 映像情報メディア学誌, 57, 10, pp.1354-1360 (2003-10)

( 8 ) T. Takegami, T. Gotoh, and G. Ohyama: "An Algorithm for ModelBased Stable Pupil Detection for Eye Tracking System", IEICE trans.-ISS, Vol.J86-D-II, No.2, pp.252-261 (2003-2) (in Japanese)

竹上 健 ・後藤敏行 · 大山 玄:「視線方向計測のための高精度瞳 孔検出アルゴリズム」, 信学論 D-II, J86-D-II, 2, pp.252-261 (2003-2)

(9) N. Takubo and T. Fujioka: "Analysis of Glance Away in Driving", Journal of Society of Automotive Engineers of Japan, Vol.34, No.2, pp.107-112 (2003) (in Japanese)

田久保宣晃・藤岡健彦：「運転中の脇見行動に関する分析」, 自動車 技術会論文集, 34, 2, pp.107-112 (2003)

(10) S. Shirai, M. Ito, Y. Norimatsu, T. Nakano, and S. Yamamoto: "Detection of the Gaze Direction for Detection of the Driver's Status", IEICE technical report, Pattern recognition and media understanding, Vol.103, No.453 (PRMU2003 151-170), pp.67-72 (2003) (in Japanese) 白井了·井東道昌・乗松 有・中野倫明・山本 新 : 「ドライバ の運転状態検知のための視線方向の検出」, 信学技法, Vol.103, No.453 (PRMU2003 151-170), pp.67-72 (2003)

(11) K. Yamamoto: "Human Interface of Driver's Attention Monitor", Journal of Society of Automotive Engineers of Japan, Vol.56, No.3, pp.74-78 (2002) (in Japanese)

山本恵一：「運転注意力モニタのヒューマンインタフェース」, 自動 車技術, 56, 3, pp.74-78 (2002)

(12) N. Kojima, k. Kozuka, T. Nakano, and S. Yamamoto: "Detecting of Consciousness Degradation and Concentration of a Driver for Friendly Information Service", Proc.2001 IEEE Int. Conf. on International Vehicle Electronics Conference, 1B-2, pp.31-36 (2001)

(13) 例えば ,E-Wahlstrom, O. Masound, and N. PapaniKolopoils: "Vision-Based Methods for Driver Monitoring", pp.12-17 (1999)

(14) 例えば , M. Itoh, B. Inagaki, S. Yamamoto, and S. Mori: "Driver's Status Monitor"—Development of the Driver's Monitor Mirror and Estimation of the Driver's Status-, $11^{\text {th }}$ World Congress on ITS Nagoya, Aich2004, Japan, \#3089, p.125 (2004)

(15) Y. Shimizu and T. Kuwabara: "A Warning System for Driving Assistance", Nissan Technical Review, No.49, pp.59-62 (2001) (in Japanese) 清水洋志・桑原達雄 : 「運転支援システムの警報における一考察」, 日 産技報, No.49, pp.59-62 (2001)

(16) T. Suetomi, T. Niibe, and H. Uemura: "Human Interface of Collision Warnings", Journal of Society of Automotive Engineers of Japan, Vol.56, No.3, pp.49-53 (2002-3) (in Japanese) 末富隆雄・新部忠幸・上村裕樹 : 「危険警報のヒューマンインタフェー ス」, 自動車技術, 56, 3, pp.49-53 (2002-3)

(17) M. Iwao, M. Kunisue, M. Kobayashi, and A. Horiguchi: "Study on Warning Sound Easy to Generate Mental Models on the Systems", Journal of Society of Automotive Engineers of Japan, No.17-03, pp.7-10 (2003) (in Japanese) 岩男䢐由美・国陶太亮・小林正巳・堀口明伯 : 「メンタルモデルを 構築しやすい警報の検討一警報音の物理特性と聴感的類似性との関 係一」, 自動車技術会学術講演会前刷集, No.17-03, pp.7-10 (2003)

(18) M. Iwao, A. Horiguchi, and M. Kobayashi: "Study on alarm sound to support driver's situation awareness", Journal of Society of Automotive
Engineers of Japan, No.34-02, pp.9-12 (2002) (in Japanese)

岩男眞由美・堀口明伯・小林正巳 :「警報信号音の特性と緊急性・ 識別についての一考察」, 自動車技術会学術講演会前刷集, No.34-02, pp.9-12 (2002)

(19) K. Ebe, K. Kimura, H. Inagaki, and S. Doi: "Characteristics of Alarms and Perceived Urgency", Journal of Society of Automotive Engineers of Japan, Vol.56, No.3, pp.27-32 (2002-3) (in Japanese)

江部和俊・木村賢治・稲垣 大・土居俊一:「緊急レベルに応じた警報 音特性一緊急度マップの提案一」, 自動車技術, 56, 3, pp.27-32 (2002-3)

(20) 山口昌広・伊藤丈裕・杉山和彦・山本 新 : 「近赤外光画像によるド ライバ状態監視システム」, 第 6 回画像センシングシンポジウム講演 論文集, D-3, pp.63-68 (2000)

(21) T. Hamada, S. Shirai, F. Kobayashi, I. Ito, M. Ito, K. Adachi, T. Nakano, and S. Yamamoto: "Detecting for Dricer's Operational State", Proceeding of $9^{\text {th }}$ Symposium on Sensing via Image Information, B-30, pp.177-182 (2003) (in Japanese)

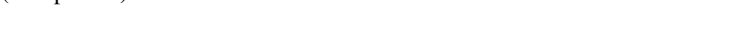
中野倫明・山本 新 : 「ドライバの運転状態の検知一個人差に対応 した閉眼時間変化からの意識低下レベルの検知一」, 第 9 回画像セン シングシンポジウム講演論文集, B-30, pp.177-182 (2003)

(22) K. Adachi, H. Yamada, H. Kobayashi, M. Itoh, T. Nakano, S. Tsugawa, and S. Yamamoto: "Development of Driving Simulator for Humanfriendly Invehicle System 1", $11^{\text {th }}$ World Congress on ITS Nagoya, Aich2004, Japan, \#3359, p.75 (2004)

(23) H. Yamasaki, T. Yamada, H. Ishigaki, T. Nakano, S. Tsugawa, and S. Yamamoto: "Development of a Driving Simulator for Human-Friendly Invehicle System 2"-An Information System Adjustable to Driver's Status and Individual Difference-, $11^{\text {th }}$ World Congress on ITS Nagoya, Aich2004, Japan, \#3360, p.302 (2004)

山 垴 初 夫 (正員) 1948 年生。1971 年 3 月名城大学理工学

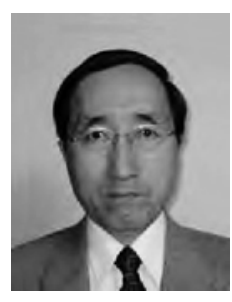
部電気工学科卒業。同年名城大学電子計算機室技 術員，1984 年同理工学部助手，1991 年同理工学 部講師 , 現在 , 名城大学情報センター助教授。現 在, ヒューマンインタフェースに関する研究に従 事。特に車載ディスプレイへの高齢者にやさしい 表示方法, 警報提示方法に関する研究に従事。電 子情報通信学会, 情報処理学会, 教育システム情 報学会, 映像情報メディア学会。

小 林史 和 (非会員) 2005 年 3 月名城大学大学院理工学研

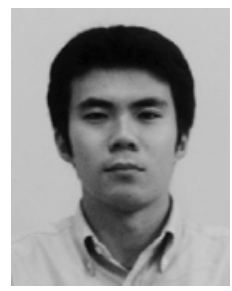
究科修士修了。同年 4 月 (株) 東海理化入社。在 学中, ドライバ状態モニターに関する研究やドラ イビングシミュレータの製作に従事。

山田 拓 郎 (非会員) 2005 年 3 月名城大学大学院理工学研

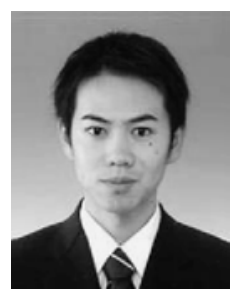
究科修士修了。2005 年 4 月卜ヨ夕紡織 (株) に 入社。在学中，運転支援システムの警報提示方法 に関する研究やドライビングシミュレータの製作 に従事。 
井 東 道 昌 (非会員) 1995 年 3 月静岡大学大学院工学研究科

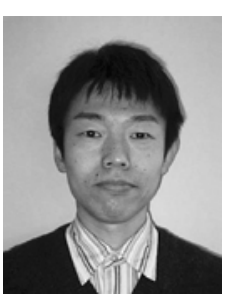

修士課程修了。同年，(株) 東海理化入社。R\&D センター開発部所属, 居眠り検知の研究開発など の担当を経て，2000 年 4 月からインナミラー内 蔵撮像システムやドライバ状態モニターの研究開 発に従事。
中

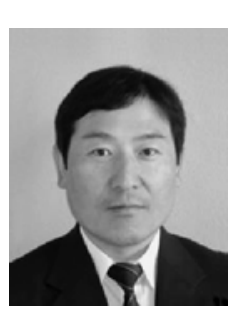

(正員) 1956 年生。1982 年 3 月名古屋大学大学 院工学研究科修士課程修了。同年, (株) 豊田中央 研究所に入社。以来, 工業用文字認識, 3 次元画 像計測・認識, ならびに車載ディスプレイの表示 などの研究開発に従事。現在, ドライバへの情報 提示など自動車における視聴覚情報処理やヒュー マンインタフェースに関する研究と教育を担当。 1999 年 10 月より名城大学理工学部助教授。現在,

同大学同学部教授。工学博士。

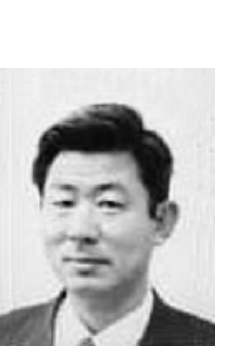

新 (正員) 1942 年生。1965 年 3 月岐阜大学工学部 電気工学科卒業。同年, (株) 豊田中央研究所に入 社。以来, 3 次元画像計測・認識,ETC $の$ 基礎技術 のマイクロ波 ID , ITS に関するマシンビジョン， 車載ディスプレイの表示などの研究開発に従事。 現在 , ドライバの状態検知を含む自動車のヒュー マンインタフェースに関する研究と教育を担当。 豊田工業大学連携大学院博士課程教授 (併任) を 経て, 1998 年より名城大学理工学部教授。工学博士。 